\title{
Killing of Gyrodactylus salaris by heat and chemical disinfection
}

Perttu Koski ${ }^{1 *}$, Pasi Anttila1,2 and Jussi Kuusela ${ }^{1,3}$

\begin{abstract}
Background: Gyrodactylus salaris is a monogenean, which has collapsed tens of wild Atlantic salmon populations. One of the means of preventing the spread of the parasite is the disinfection of the fishing equipment, which is used in the rivers having susceptible salmon populations. Little is known about the dosage of disinfectants against $G$. salaris. There are not standards for the testing of disinfectants against multicellular parasites. The present investigation developed a method to test disinfectants and examined the effectiveness of heated water and a commercially available disinfectant (Virkon S) in killing G. salaris. Individual G. salaris worms were followed under the microscope during treatment with heated water or Virkon S disinfectant blend. The logarithm of the time needed to kill the parasite was used as a dependent variable in linear regression. The upper $99.98 \%$ prediction line for the dependent variable was used to obtain a value resembling the time needed for a 4 log reduction of the microbial pathogen, which is commonly used as a criterion for disinfectants. Also 6 log reduction was applied.
\end{abstract}

Results: Exposure to a relatively low temperature was found to kill the parasite. Even 5-50 min treatment (=10-100 times the $99.98 \%$ upper prediction value) with heated water at $40{ }^{\circ} \mathrm{C}$ might be used. This would enable the utilisation of hot tap water in the disinfection of fishing gear. The present practice of $1 \%$ Virkon S for 15 min was also found to kill the parasite.

Conclusions: The follow-up of single parasites of a test population and the use of the calculated upper predictive line in the regression analysis offers a method to analyse the effects of disinfectants on parasites like G. salaris. The results of our tests give possibilities for using disinfection methods, which may be more acceptable by the fishermen than the present ones.

\section{Background}

Gyrodactylus salaris Malmberg 1957 was first identified on farmed Atlantic salmon (Salmo salar L.) at a fish farm in the Baltic Sea catchment area [1]. Since the 1970s, G. salaris has collapsed populations of wild Atlantic salmon in tens of Norwegian rivers and one Russian river [2, 3]. The parasite is widespred in the Baltic Sea catchment area [4-8]. Measures to prevent the spread of the parasite include prohibition of the transport of live fish to rivers containing wild Atlantic salmon unless the source of the fish is known to be free of G. salaris [9], barriers to stop fish migration upstream from infected river areas to

\footnotetext{
*Correspondence: perttu.koski@evira.fi

${ }^{1}$ Production Animal and Wildlife Health Research Unit, Finnish Food

Safety Authority Evira, Elektroniikkatie 3, 90590 Oulu, Finland

Full list of author information is available at the end of the article
}

uninfected ones, and eradication of infection in rivers by chemical treatment $[3,10,11]$.

Although the risk of the spread of G. salaris by fishing equipment was not regarded very big [12], have national authorities in Finland, the United Kingdom and Norway provided guidelines or legal regulations on the disinfection of fishing equipment in order to prevent the spread of G. salaris to water systems free of the parasite [13-15]. Temperature (heating of equipment to $60^{\circ} \mathrm{C}$ for $1 \mathrm{~h}$ ) and the use of a commercial disinfectant blend (Virkon S) have been advised in addition to complete drying or freezing of the equipment. The suggested concentrationtime combination for Virkon S, when mentioned in these instructions, has been at least $1 \%-15 \mathrm{~min}$. Some fishermen, especially anglers, fear that the use of disinfectants will harm their valuable equipment. This might reduce

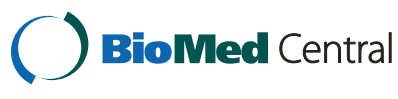

(c) 2016 Koski et al. This article is distributed under the terms of the Creative Commons Attribution 4.0 International License (http://creativecommons.org/licenses/by/4.0/), which permits unrestricted use, distribution, and reproduction in any medium, provided you give appropriate credit to the original author(s) and the source, provide a link to the Creative Commons license, and indicate if changes were made. The Creative Commons Public Domain Dedication waiver (http://creativecommons.org/ publicdomain/zero/1.0/) applies to the data made available in this article, unless otherwise stated. 
their willingness to undertake proper disinfection and perhaps jeopardise the preventive measures.

To our knowledge there are no international standards for the testing of the effect of disinfection of G. salaris. The European Committee for Standardisation has not provided norms for the testing of antiparasitic disinfectants [16]. The guidelines of the German Association of Veterinary Medicine provide advice for parasite eggs and Coccidia oocysts, but not for adult worms [17].

The present investigation examined the effectiveness of heated water and a commercially available disinfectant (Virkon S) in killing G. salaris. A simple testing method was developed to examine the lethal effect of disinfection on G. salaris. The aim was to examine the time needed to kill the parasite, when lower temperatures and concentrations of Virkon $\mathrm{S}$ than the present recommendations are used.

\section{Methods}

\section{Fish}

All rainbow trout (Oncorhynchus mykiss Walbaum) used in our experiments were one summer old, ca. $20-25 \mathrm{~cm}$ in length and obtained from a commercial fresh water fish farm in Northern Finland. The fish were transported to the laboratory in hatchery water and were maintained in two $500 \mathrm{l}$ plastic fish tanks before the experiments. The tanks were sited in a thermostat-regulated room with a constant temperature of $10^{\circ} \mathrm{C}$. Before the tests involving increasing temperature, the fish and parasites were acclimated to $6{ }^{\circ} \mathrm{C}$ for 1 week. The fish were not fed during their stay in the laboratory. Tanks were aerated and had an internal recirculation of water with a sand filter.

\section{Parasites}

Because it was assessed too difficult to get the worms unharmed onto the fishing equipment, G. salaris in their natural habitat, on the fish fin, were used. The rainbow trout were infected with rainbow trout type G. salaris (GenBank accession number AF479750) at the farm, from where they were transported to the laboratory. The species of Gyrodactylus was determined by molecular analysis of the mitochondrial $\mathrm{CO} 1$ sequence as described in [18].

The parasite survival was followed in the test system at $10{ }^{\circ} \mathrm{C}$ (before acclimatizing the fish and parasites to $6^{\circ} \mathrm{C}$ ). The parasites were found to live up to $85 \mathrm{~h}$. After $48 \mathrm{~h}$ the fin and the parasite were already covered with a thick layer of slime and detached epithelium from the fin, but the parasites remained alive.

\section{Test design}

In thermal treatments, each fish was killed with a blow on the head and fins were immediately cut while the fish were submerged in tank water. Parasitized fins were individually placed in a Petri dish in heated water from a tank water container. Parasites (1-3 individuals at a time) were continuously observed and the survival time was recorded with a stopwatch. When the parasite complex (including mother G. salaris and daughters in her uterus) stopped moving, the worm was gently irritated with an insect needle. In many cases, the parasites responded to irritation. The stopwatch was halted when the parasite did not move nor react to needle stimulation. The fins were handled similarly in the testing of Virkon S. Parasites were observed and the survival time was measured as in the tests with elevated temperature.

The possible recovery of $G$. salaris after the termination of its movements was tested by transferring the fin and attached parasite to fresh water. The amount of the disinfectants concurrently transferred on the surface of the parasite and fin was found to be negligible, as the median volume of water carried with the moved fin was ca. $37 \mu \mathrm{l}$ (7 weight measurements). If this volume of $1 \%$ Virkon S solution was mixed with the $65 \mathrm{ml}$ of freshwater used in the test, the resulting concentration of Virkon $\mathrm{S}$ would be ca. $5.7 \times 10^{-4} \%$. Based on the results it was concluded that the worms, which had lost their ability to move, could not recover and were dead.

\section{Tests with elevated temperature}

Thermal treatments were performed using a thermostatregulated heating block (Fig. 1). In addition to the heating block, the desk lamp also heated the water. In the first test, $65 \mathrm{ml}$ of tank water in a Petri dish was quickly heated to the test temperature $\left(25,30,35\right.$ or $\left.40{ }^{\circ} \mathrm{C}\right)$. The fin with the 1-3 parasites on it was then put to the preheated water and the time for the death of the parasite(s) recorded according to the protocol presented in the paragraph 'Test design'. The water temperature was monitored during the tests, and the water was not aerated.

In the second test the temperature was slowly elevated from $6{ }^{\circ} \mathrm{C}$ until each worm ceased moving. This varied between 760 and $2359 \mathrm{~s}$ depending on the speed of the elevation of the water temperature. The rate of increase of the temperature was regulated by changing the distance of the desk lamp from the microscope. The time when the worm no longer moved even after the irritation by an insect needle was recorded as the time of death.

\section{Tests with Virkon S}

Virkon $\mathrm{S}$ is a commercial oxidising disinfectant blend. The product used in the experiments described here (produced by Antec Int. Ltd, UK.) was labelled as containing the following: potassium peroxymonosulphate, sodium hexametaphosphate, sodium alcylbenzenesulphonate, malic acid, sulphamic acid, sodium chloride, 


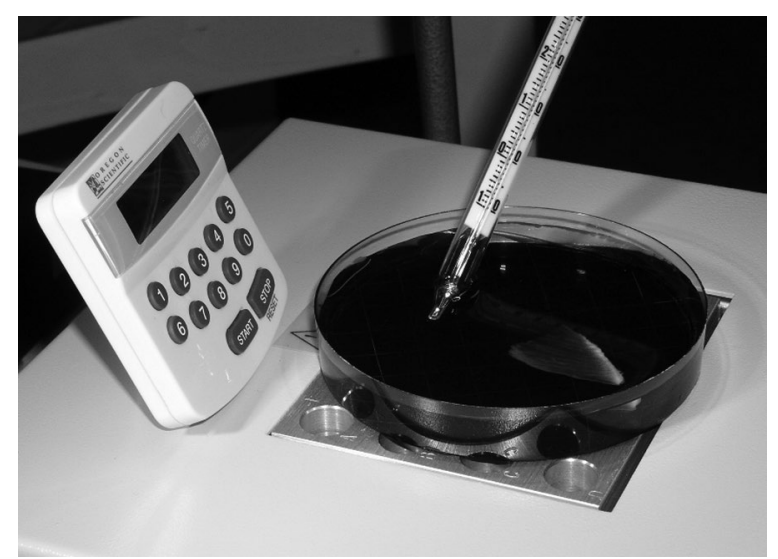

Fig. 1 Test apparatus. Gyrodactylus salaris individuals were attached on a rainbow trout fin that was placed in $65 \mathrm{ml}$ of fish tank water. The temperature of the water was maintained (or raised by heating with a desk lamp in the second experiment on heat disinfection) by the heat block under the Petri dish and followed with the thermometer. The survival time of individual parasites was recorded with the stopwatch

fragrance and an indicator dye. Virkon $S$ is widely used in the disinfection of livestock premises and in aquaculture.

All experiments with Virkon $S$ solution were performed at $10{ }^{\circ} \mathrm{C}$. Virkon $\mathrm{S}$ concentrations of $0.01,0.05,0.1$ and $1.0 \%$ were tested. The time until the mother and the daughter parasite did not move even after the irritation with an insect needle was recorded and used as the time of the death of the parasite.

\section{Statistics}

Regression analysis was used to test the association between the temperature and survival time and between Virkon S concentrations and survival time. Logarithmic transformations of the original parameters were used, because there appeared to be difficulties in fulfilling the requirement of linearity in regression analysis [19]. The residuals of the logarithmic time variable followed a normal distribution.

The upper $99.98 \%$ prediction line in the regression analysis was used as an estimate for the time needed to reduce the G. salaris population by $4 \log$. The $6 \log$ reduction was counted on the basis of only $10^{-6}$ of the normally distributed population lying outside $\pm 5 \times$ standard deviation of the mean.

Statistical analysis was carried out using the analytical software package SPSS for Windows version 22 [20].

\section{Results}

Effect of water temperature on the survival time of G. salaris

Gyrodactylus salaris was sensitive to treatment with warm water (Table 1 ), as the individual worms only survived for $6-18 \mathrm{~s}$ in $40^{\circ} \mathrm{C}$. The water temperature and the time until the cessation of movements were found to be associated and the following linear regression formula was obtained $\left(\mathrm{R}^{2}=0.98, P<0.001\right)$ :

$$
\log \mathrm{TIME}=8.72-0.20 \times \text { TEMPERATURE }\left({ }^{\circ} \mathrm{C}\right) .
$$

On the basis of this and Fig. 2 it can be concluded that there is a clear killing effect of the increased temperature. Another regression was also tested in which both variables were logarithmically transformed, but $\mathrm{R}^{2}$ remained the same (0.98).

The higher $99.98 \%$ individual prediction line indicates a survival time of ca. $30 \mathrm{~s}$ for G. salaris in $40{ }^{\circ} \mathrm{C}$. If the $99.98 \%$ confidence limits for the prediction interval are extrapolated to the temperature at which the predicted survival time of the parasite would be $10 \mathrm{~s}, 42.5^{\circ} \mathrm{C}$ would be sufficient to stop all movement of the parasite. The 1-s treatment temperature would be $47.6{ }^{\circ} \mathrm{C}$. The more critical requirement of $6 \log$ reduction [7] - ca. 5 times the standard deviation from the mean-in $40{ }^{\circ} \mathrm{C}$ would be $34 \mathrm{~s}$. This is not very much higher than the $4 \log$ reduction time.

The results of the experiment in which the temperature was gradually raised are illustrated in Fig. 3. It appeared that G. salaris had a fairly constant lethal temperature of $30.5-33.5^{\circ} \mathrm{C}$, irrespective of the time taken (13 $\mathrm{min} 20 \mathrm{~s}-40 \mathrm{~min}$ ) to reach this temperature. In the regression analysis the regression coefficient was 0.00 $\left(\mathrm{R}^{2}=0.22\right)$.

Table 1 The survival times of Gyrodactylus salaris in heated water and Virkon S

\begin{tabular}{|c|c|c|c|c|}
\hline Temperature $\left({ }^{\circ} \mathrm{C}\right)$ & +25 & +30 & +35 & +40 \\
\hline Survival time [median (range)] & $119.7(67.4-209.3) \mathrm{min}$ & $12.4(6.9-21.6) \mathrm{min}$ & $50.5(36-98) \mathrm{s}$ & $9(6-18) s$ \\
\hline $\mathrm{N}$ & 18 & 36 & 40 & 23 \\
\hline Virkon S (\%) & 0.01 & 0.05 & 0.1 & 1.0 \\
\hline Survival time [median (range)] & $11.7(3.4-34.2) \mathrm{min}$ & $3.1(1.8-4.8) \mathrm{min}$ & $2.4(1.4-4.5) \mathrm{min}$ & $14(8-28) \mathrm{s}$ \\
\hline $\mathrm{N}$ & 54 & 54 & 55 & 53 \\
\hline
\end{tabular}

The survival times of single worms in different water temperatures (upper) and Virkon S (below)

$N$ number of worms tested 


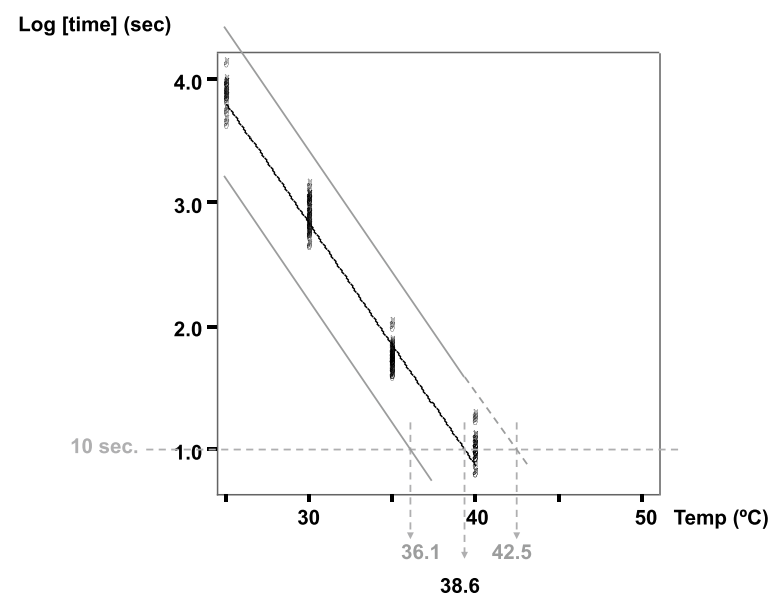

Fig. 2 Relationship between the time to death of Gyrodactylus salaris and the water temperature. Scatter diagram, linear regression line (middle line) and the $99.98 \%$ prediction lines for future individual observations (upper and lower lines) relating the fixed disinfection water temperatures $\left(25,30,35\right.$ and $\left.40{ }^{\circ} \mathrm{C}\right)$ to the logarithm of the survival time of $G$. salaris

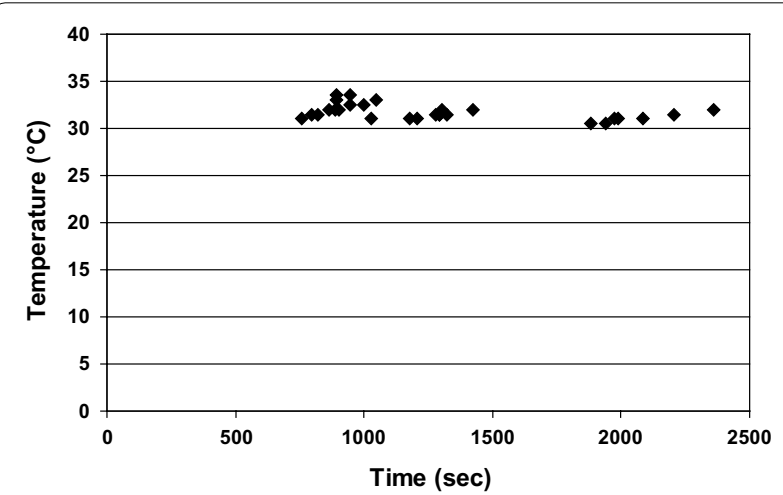

Fig. 3 Lethal temperature of Gyrodactylus salaris. The temperature at which $G$. salaris were killed when the water temperature was slowly elevated from $6{ }^{\circ} \mathrm{C}$ to the lethal temperature. The time of the death of G. salaris is plotted on the $x$-axis

\section{Survival time in Virkon S}

The survival of G. salaris in Virkon $S$ is shown in Table 1. The time until the cessation of movement of G. salaris and the Virkon $S$ concentration were found to be associated and the following linear regression formula was obtained $\left(\mathrm{R}^{2}=0.93, P<0.001\right)$ :

$$
\log \text { TIME }=-0.47-0.84 \log \text { CONCENTRATION. }
$$

The test results are illustrated in Fig. 4. The higher $99.98 \%$ individual prediction line indicates a survival time of $484 \mathrm{~s}$ for G. salaris in a $0.1 \%$ solution (one tenth of the standard concentration) and $17 \mathrm{~s}$ in $1 \%$ solution of Virkon $\mathrm{S}$. The more critical requirement of $6 \log$ reduction [21] in $1 \%$ solution was counted to be ca. $102 \mathrm{~s}$.

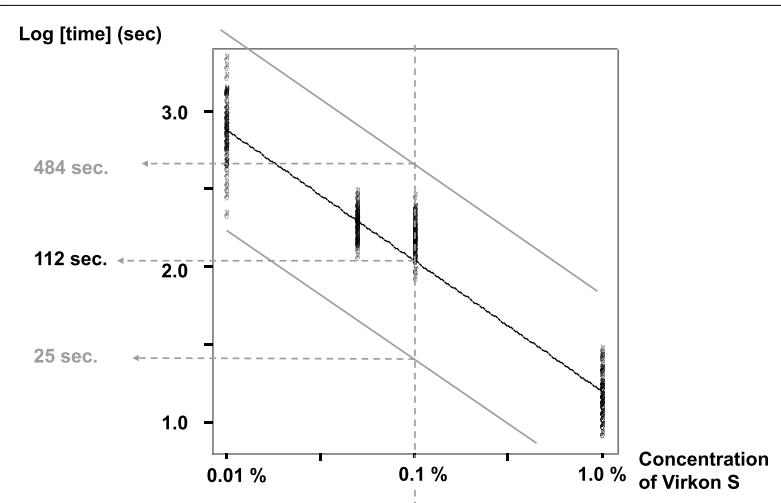

Fig. 4 Relationship between the time to death of Gyrodactylus salaris and the concentration of Virkon S. Scatter diagram, linear regression line (middle line) and the $99.98 \%$ prediction lines for future individual observations (upper and lower lines) relating the logarithm of the concentration of Virkon S (\%) to the logarithm of the survival time of G. salaris

\section{Discussion}

Freshly cut rainbow trout fin is most likely a better living environment for G. salaris than the surface of fishing equipment. The parasites may tolerate the action of disinfectants, if they thrive well. This may divert the estimations of the survival time of the parasite in a safe direction. On the other hand the presence of extraneous substance like slime may be more probable in the surrounding of the parasite on the fin than on the surface of fishing equipment. The influence of such extraneous material probably divert the estimations to other direction [22], when the applicability of our results to the practical disinfection of fishing gear is considered.

Disinfection that reduces a bacterial, fungal or viral titre by 4-5 logs is commonly regarded as effective $[16,23,24]$. The $6 \log$ reduction is used, when medical devices are designated to be sterile according to [21]. The $99.98 \%$ prediction interval for individual G. salaris was used here for counting the $4 \log$ reduction of $G$. salaris. One ten thousandth part of the G. salaris population used in the test would stand longer disinfection times than the upper $99.98 \%$ prediction line. Killing times above this line were considered to reduce the $G$. salaris population by $4 \log$. The basis for selecting the 4 $\log$ reduction instead of $5 \log$ was the assumption that relatively low number of $G$. salaris do attach to fishing gear under real conditions.

\section{Effect of water temperature on the survival of G. salaris}

Study of the biology of G. salaris has naturally focused on physiological water temperatures [25]. According to Office International des Epizooties [26], the tolerance of G. salaris to temperatures above $25^{\circ} \mathrm{C}$ is unknown. The 
temperature and time needed to kill G. salaris in this study was much lower than that used for the general disinfection of fish farms [26]. Heat can be used in the disinfection of fishing equipment, but the advice of the [13] $-60{ }^{\circ} \mathrm{C}$ for $1 \mathrm{~h}$-is very much higher than the time needed to kill the parasite with heated water in this study. The short time of survival (movement) of the parasite at high temperature did not allow temperatures higher than $40^{\circ} \mathrm{C}$ to be tested. The extrapolated temperature $\left(42.5^{\circ} \mathrm{C}\right.$, Fig. 2) required to kill the parasite after a 10-s treatment is, however, close to the highest tested temperature and probably a good estimate of the actual lethal temperature in dipping disinfection lasting $10 \mathrm{~s}$, if $4 \log$ reduction would be the goal.

A margin of safety may be applied in the practical disinfection procedures in addition to the 4-5 log reduction of the pathogen. In the review by [27] of the general protocols for effective iodophor disinfection of viral haemorrhagic septicaemia (VHS) virus on salmonid eggs, this margin appeared to increase the treatment time by a factor of ca. 10. The present norm for heat treatment $\left(60{ }^{\circ} \mathrm{C}\right.$ for $1 \mathrm{~h}$ ) could probably be much lowered without jeopardising the efficiency of disinfection. A treatment time as low as $5-50 \mathrm{~min}(=10-100$ times the $99.98 \%$ upper prediction value) with heated water at $40{ }^{\circ} \mathrm{C}$ could be used, if a factor of 10-100 was applied.

The results of the second test examining the effect of temperature on G. salaris survival supported the use of heated water: the parasite died when the increasing water temperature reached a fairly moderate level.

The killing effect of the temperature treatments might be associated with the decreased oxygen concentrations of the heated water and not the temperature per se. There is ca. $8.1 \mathrm{mg} \mathrm{l}^{-1}$ dissolved oxygen (D.O.) in fully saturated water at $25{ }^{\circ} \mathrm{C}$ and $6.6 \mathrm{mg} \mathrm{l}^{-1}$ at $40{ }^{\circ} \mathrm{C}$. Because the heated water was only kept for a short time in a broad-mouthed vessel (Petri dish), it is unlikely that the saturation would have significantly decreased from the full saturation in the tank water of live fish. We are unaware of the limits for G. salaris, but the host fishes do not thrive at D.O. $<5 \mathrm{mg} \mathrm{l}^{-1}$ [28]. It is unlikely that the requirements of G. salaris exceed those of the host fish.

In this study the parasites were, however, treated in warm water, whereas practical disinfection procedures usually involve moist or dry heat, the thermal conductivity of which is much lower. The heated water in this study could therefore be more effective in killing the parasite than disinfection with moist or dry heat. The total energy required to elevate the temperature of the parasite is small due to the small size of the animal.

\section{Effect of low concentrations of Virkon S on the survival of G. salaris}

Virkon S proved to be efficient in killing G. salaris. Even one tenth of the standard concentration of the solution resulted in death of the parasite in less than $10 \mathrm{~min}$. This would enable the use of Virkon $S$ in lower concentrations than currently recommended. If a similar margin of safety as discussed in the section on heat disinfection (factor 10-100) was applied, the disinfection time for $0.1 \%$ Virkon $\mathrm{S}$ would, however, be impractical (1 h $37 \mathrm{~min}-16$ h $8 \mathrm{~min}$ ).

The present guideline of $1 \%$ Virkon $\mathrm{S}$ for $15 \mathrm{~min}$ is long enough both on the basis of the evaluation according to $4 \log$ reduction with a safety factor of $10-100$ or $6 \log$ reduction.

\section{Conclusions}

The demonstrated vulnerability of G. salaris to even a moderate heating of the water has practical applications. The lethal temperature to G. salaris is unlikely to damage even the most delicate angling equipment such as the line and flies. The short time needed to kill the parasite at temperatures over $40{ }^{\circ} \mathrm{C}$ allows the use of routine facilities such as hot tap water to disinfect small fishing equipment. The use of moist or dry heat in sauna or drying cabinet would need more evaluation before the present advice could be safely lowered.

\section{Authors' contributions}

All authors participated in the design of the study. PK made the statistical analysis and drafted the manuscript. PA carried out the tests; JK made the species determination of the parasites. All authors read and approved the final manuscript.

\section{Author details \\ ${ }^{1}$ Production Animal and Wildlife Health Research Unit, Finnish Food Safety Authority Evira, Elektroniikkatie 3, 90590 Oulu, Finland. ${ }^{2}$ Present Address: Perämeren Kalatalousyhteisöjen Liitto, Piuhatie 8, 90620 Oulu, Finland. \\ ${ }^{3}$ Present Address: Lahti University of Applied Sciences, Niemenkatu 73, 15140 Lahti, Finland.}

\section{Acknowledgements}

We are grateful to Professor Antti Oksanen for constructive criticism of the study during both the performing and writing up of the work. The remarks of the referees greatly improved the original manuscript. The study was financially supported by the Ministry of Agriculture and Forestry of Finland.

\section{Competing interests}

The authors declare that they have no competing interests. The authors have not received funding or other financial support from the producer of Virkon S.

Received: 19 December 2015 Accepted: 16 March 2016

Published online: 23 March 2016

\section{References}

1. Malmberg G. Om förekomsten av Gyrodactylus på svenska fiskar. Skrifter utgivna av Södra Sveriges Fiskeriförening, Årsskrift. 1956;1957:19-76.

2. Kudersky LA, leshko El, Schulman B. Distribution range formation history of the Monogenean Gyrodactylus salaris, Malmberg, 1957-a parasite of juvenile Atlantic salmon Salmo salar Linnaeus, 1758. In: Veselov AJ, leshko EP, Nemova NN, Sterligova OP, Shustov Y, editors. Petrozavodsk: Russian Academy of Sciences, Karelian Research Center, Institute of Biology; 2003. p. $77-83$ 
3. Mo TA. Status of Gyrodactylus salaris problems and research in Norway In: Pike AW, Lewis JW, editors. Parasitic diseases of fish. Dyfed: Samara Publications Ltd; 1994. p. 43-56.

4. Malmberg G, Malmberg M. Species of Gyrodactylus (Platyhelminthes, Monogenea) on salmonids in Sweden. Fisheries Res. 1993;17:59-68.

5. Koski P, Malmberg G. Occurrence of Gyrodactylus (Monogenea) on salmon and rainbow trout in fish farms in northern Finland. Bull Scand Soc Parasitol. 1995;5(76-88):146.

6. Kuusela J, Zietara MS, Lumme J. Hybrid origin of Baltic salmon-specific parasite Gyrodactylus salaris: a model for speciation by host switch for hemiclonal organisms. Mol Ecol. 2007;16:5234-45.

7. Rokicka M, Lumme J, Zietara MS. Identification of Gyrodactylus ectoparasites in polish salmonid farms by PCR-RFLP of the nuclear ITS segment of ribosomal DNA (Monogenea, Gyrodactylidae). Acta Parasitol. 2007; doi:10.2478/s11686-007-0032-1

8. Anttila P, Romakkaniemi A, Kuusela J, Koski P. Epidemiology of Gyrodactylus salaris (Monogenea) in the River Tornionjoki, a Baltic wild salmon river. J Fish Dis. 2008;31:373-82

9. The Commission of the European Communities: Commission Regulation (EC) No 1251/2008 of 12 December 20008. Off J Eur Union. 2008, L337:41-75.

10. Johnsen BO, Brabrand $\AA$, Jansen PA, Teien H, Bremset G. Evaluering av bekjempelsesmetoder for Gyrodactylus salaris. Direktoratet for Naturforvaltning. 2008. http://www.miljodirektoratet.no/old/dirnat/attachment/148/Utredning\%202008-7\%20Evaluering\%20av\%20bekjempelses. pdf. Accessed Feb 22016.

11. Miljødirektoratet. Handlingsplan mot lakseparasitten Gyrodatylus salaris for perioden 2014-2016. Miljødirektoratet. 2014. http://www.miljodirektoratet.no/Documents/publikasjoner/M288/M288.pdf. Accessed Feb 2 2016.

12. Vitenskapskomiteen for mattrygghet. Vurdering av risiko for spredning av Gyrodactylus salaris knyttet til ulike potensielle smitteveier. 2005. http:// www.vkm.no/dav/9b40351568.pdf. Accessed Feb 22016

13. Finnish Food Safety Authority Evira. Protect the salmon-prevent the spread of salmon parasite Gyrodactylus salaris. 2015. http://www.evira. fi/portal/en/about+evira/publications/?a=category\&cid=32. Accessed February 22016.

14. Scottish Executive Environment and Rural Affairs Department (SEERAD). Gyrodactylus salaris - What you need to do. 2011. http://www.gov.scot/ Topics/marine/Fish-Shellfish/18364/18610/diseases/notifiableDisease/gsalaris/gsactions. Accessed Feb 2016.

15. Norwegian Food Safety Authority. Help us keep our fish healthy. How to stop the spread of Gyrodactylus salaris. 2015. http://www.mattilsynet.no/ language/english/fish_and_aquaculture/recreationalfishing/how_to_ stop_the_spread_of_gyrodactylus_salaris_2015_engelsk.10035/binary/ How\%20to\%20stop\%20the\%20spread\%20of\%20Gyrodactylus\%20salaris,\%202015\%20engelsk. Accessed February 22016.
16. European Committee for Standardization. Chemical disinfectants and antiseptics. Application of European Standards for chemical disinfectants and antiseptics. 2007, European Standard EN 14885:1-34.

17. Böhm R. Desinfektionsmittelliste der Deutschen Veterinärmedizinischen Gesellschaft (DVG) für die Tierhaltung. Hanover: Schlütersche GmbH \& Co; 2003. p. 1-12.

18. Meinilä M, Kuusela J, Zietara MS, Lumme J. Primers for amplifying 820 bp of highly polymorphic mitochondrial COI gene of Gyrodactylus salaris. Hereditas. 2002:137:72-4.

19. Sokal RR, Rohlf FJ. Biometry: the principles and practice of statistics in biological research. New York: W. H. Freeman and Company; 1995.

20. Anonymous SPSS for Windows version 22. 2013.

21. British Standard: Sterilization of medical devices-requirements for medical devices to be designated "STERILE" —Part 1. Requirements for terminally sterilized medical devices. BS EN 556-1: 2001 Incorporating Corrigendum No 1, 2006: p. 1-8.

22. OIE (World Organisation for Animal Health). Aquatic Animal Health Code: general recommendations on disinfection. 2015, http://www.oie.int/ index.php?id $=171 \& \mathrm{~L}=0 \&$ htmfile=chapitre_disinfection.htm. Accessed Feb 172016.

23. Slavin G. A reproducible surface contamination $\cdot$ method for disinfectan tests. Br Vet J. 1973;129:13-8.

24. Mazzola PG, Penna TC, Martins AM. Determination of decimal reduction time ( $D$ value) of chemical agents used in hospitals for disinfection purposes. BMC Infect Dis. 2003;3:24.

25. Bakke TA, Cable J, Harris PD. The biology of gyrodactylid monogeneans: the "Russian Doll-killers". In: Baker JR, Muller R, Rollinson D, editors. Advances of parasitology. 2007. p. 161-376

26. OIE (World Organisation for Animal Health): Aquatic Animal Health Code, Infection with Gyrodactylus salaris. 2012. http://www.oie.int/fileadmin/ Home/eng/Health_standards/aahm/current/2.3.03_GYRO.pdf. Accessed Feb 282016.

27. Bovo G, Hill BJ, Husby A, Håstein T, Midtlyng PJ, Olesen NJ, Storset A: Work package 3 report. Pathogen survival outside the host, and susceptibility to disinfection. 2005, Contract no QLK2-CT-2002-01546 (European Commission). p. 1-41.

28. Rosenthal H, Munro ALS. Der aquatische Lebensraum Umweltbedingungen in natürlichen Gewässern und Aquakulturanlagen. In: Roberts RJ, Schlotfeldt H, editors. Grundlagen der Fischpathologie. Berlin: Verlag Paul Parey; 1985. p. 1-22.

\section{Submit your next manuscript to BioMed Central and we will help you at every step:}

- We accept pre-submission inquiries

- Our selector tool helps you to find the most relevant journal

- We provide round the clock customer support

- Convenient online submission

- Thorough peer review

- Inclusion in PubMed and all major indexing services

- Maximum visibility for your research

Submit your manuscript at www.biomedcentral.com/submit
() Biomed Central 